\title{
Review
}

\section{Die privat-öffentliche Achse des Politischen. Das Unvernehmen zwischen Hannah Arendt und Jacques Rancière}

\author{
Ivana Perica (ed.) \\ Königshausen and Naumann, Würzburg, 2016, 375 pp., \\ ISBN: 978-3-8260-5712-0
}

Contemporary Political Theory (2018) 17, S74-S77. https://doi.org/10.1057/s41296017-0109-z; published online 24 March 2017

Ivana Perica turns to the work of Arendt and Rancière to examine how 'the political left' (represented in political theory) has changed its approach to dealing with the relation between public and private. 'The Liberals' are understood as theorists, arguing for an essentialist and static meaning of 'the Public' and 'the Private'. They are looking for the best way to describe what 'the Public' and 'the Private' actually are. 'The Left' oppose the idea of essentialist and closed spheres. They imagine the concepts of public and private as dynamic and fluid (p. 7). According to Perica's main thesis, 'the Left' does not only criticise the liberal idea of public and private but has also started to discuss useful semantics of the two categories. In the past, 'the Left' have only questioned the existing repressive use of the categories and tried to change their meaning, culminating in the phrase 'the personal is political'. Today, however, it can be seen that neoliberalism has changed economy and state, so the 'old' critique of 'the Left' doesn't fit any more (p. 9). Today, 'the Left' doesn't aim at deconstructing the categories of public and private but at their 'discursive understanding' (p. 10).

Perica highlights the challenge of schematizing positions like 'the Left' and 'the Liberals' and the problem of determining who belongs to which position and why. She demonstrates this with her main protagonists: Hannah Arendt and Jacques Rancière. Rancière calls Arendt a liberal (just like many other political theorists did) and finds fault with her public-private dichotomy as belonging to a liberal tradition. However, Perica insists, Arendt is not a liberal but actually the opposite: a persuasive critic of the liberal public-private dichotomy (p. 73). One of Perica's strengths is not to be misguided by categorisations like 'left' and 'liberal' in her analysis but to carefully read her protagonists instead. She produces convincing and close readings of Arendt and Rancière. Bringing her protagonists together is not an

(C) 2017 Macmillan Publishers Ltd. 1470-8914 Contemporary Political Theory Vol. 17, S2, S74-S77 
easy enterprise. Her analysis is held together by locating the two within a shared horizon on central topics like 'the common', beginning (arché) and emancipation.

Repeatedly, Perica expounds the problem of imprecise or even incorrect reception of Arendt by political theorists. Concerning Rancière, Perica's thesis is that his obsessive demarcation of Arendt's position is strategic. Perica accuses Rancière of making extensive statements about her theory while not reading Arendt closely enough as well as not reading her sufficiently (p. 188). Perica rereads Arendt's discussion of the semantic change of public-private relations from the ancient to the modern age. Arendt has often been understood to transfer the ancient model to today, thereby importing the inequality presupposed by the ancient model into her own understanding of the political. However, Perica makes clear that this was a false reading of Arendt's approach.

Perica understands Arendt's discussion of the ancient model as more differentiated. Arendt did not mean to transfer the ancient model wholesale but, rather, tried to locate certain necessities for acting politically, which the ancient model hints toward (p. 103). Perica opposes an essentialist understanding of Arendt's concepts of public and private as interpreted by Arendt's critics such as Seyla Benhabib. Contrary to Benhabib, Perica sees a dynamic relation of public and private in Arendt's theory that does not clearly define the objects of what is political and what is not. Referring to Rahel Jaeggi, she shows that, for Arendt, everything can become political but it has to be politicised (p. 112). Perica's reading of Arendt's understanding of 'the social' is ambivalent. On the one hand, Perica defends Arendt's distinction between the social and the political. On the other hand, she seems not to understand why Arendt differentiates between the two. Again, Perica argues against the reception of Arendt that accuses her of pushing aside 'the social question' in her understanding of the political (p. 162). But the reason for Arendt's critique of the amalgamation of the social question with the political in the modern age remains unclear.

Perica makes the interesting observation that, although Rancière claims that he does not draw any line between the social and the political, in fact, his own approach relies on this separation (p. 160). Since Perica's main question is how 'the left' has changed its approach to public-private relations, as one protagonist of 'the left', Rancière is a central figure of Perica's book. Besides the strong demarcation from Arendt's position, Perica refers to Rancière's turning away from poststructuralist theory. He distances himself from the mainstream vocabulary of poststructuralism and uses his own words to refer to similar phenomena. Instead of 'discourse', 'subject' or 'the real', he speaks of 'spontaneous subjectivation' (spontane Subjektivierung), 'sensual existence' (sinnliche Existenz) and 'sensus communis' (p. 115).

Rancière also argues against political theorists who have not realised that neoliberalism changes the semantics of public and private and therefore that political resistance á la 'the personal is political' does not work since the dominant

(c) 2017 Macmillan Publishers Ltd. 1470-8914 Contemporary Political Theory Vol. 17, S2, S74-S77 S75 
categories of political discourse do not refer to the separation of 'the political' and 'the non-political' any more (p. 134). Rancière calls state and economy 'the police'. It is the non-political political. His opposite is the demos, the political non-political (p. 135). Rancière's political theory is a critique of institutionalised politics. He transfers the 'true political' and the impulse of emancipatory change to the demos. True politics is 'the uncovering of the democratic wrong, that leaves identarian particularism behind ... and lets the demos appear as political subject' (pp. 117-118, my translation). Perica describes his understanding of the political as making things visible. In this sense, he uses the public-private relation. It is a discursive project, leaning on the aesthetic. It is also performative and bound to the 'event'. It is not essential and not bound to a sphere or area of (social) space (p. 137).

Perica shows that Rancière has more in common with Arendt than he would like to admit. Their common initial point is the human ability to speak (p. 149f). Acting politically is a human phenomenon, because it is only humans who are able to speak (as a world building practice). The ability to speak is not a guarantor for entering the political. It is rather a tool for emancipation (p. 153). Another common topic is 'arché' (the problem of the new) as a central figure of the political (p. 187). Arendt connects 'the problem of the new' with natality. It is the idea that political practice means starting something that has not existed before, which comes into being through political practice. For Arendt and Rancière, the ability to start something new is linked to the demos, not to political institutions. Perica differentiates between Arendt's revolutionary and Rancière's evolutionary understanding of arché (p. 214).

Rancière's and Arendt's understandings of the common cut across their respective conceptualizations of the public-private relation. On the one hand, Perica sees an important link between the two. Their discussion of 'sensus communis' is a discussion of the possibility of critique and the aesthetic character of the political (p. 265). Perica sees a link of the aesthetic to the idea of narrative political practice that enables new identities (p. 266). This idea is consistent with Arendt's as well as with Rancière's political-theoretical narration (p. 275). The aesthetic is the only place for resistance and distance from the social (p. 276). On the other hand, Perica highlights a significant difference in Arendt's and Rancière's discussion of 'the common'. Perica refers to the performative character of 'the common' in Arendt. She does not assume an essentialist common ground (or set of norms) that generates a community. It is the other way around: acting together produces community and a shared world (p. 257). For Rancière, in contrast, the common presupposes a partition that needs to be uncovered in order to create community (p. 265).

In her final chapter on the politics of education, Perica focuses on the centrality of the question of pedagogy for emancipatory politics. Perica's question is how 'freedom for everybody' can be enabled (p. 286). Perica shows how Arendt and 
Rancière both argue against any pedagogical formation of political subjects (p. 285). Plato's and Aristotle's model of the state integrates pedagogical influence and forming of state subjects in their understanding of successful state-building, while Arendt and Rancière oppose any elitist approach to politics. For Perica, the integration of pedagogy in political theory is important in order to address the problem of 'freedom for everybody'. Yet, neither Arendt's nor Rancière's accounts of pedagogy are wholly successful. On the one hand, for Arendt the question is not 'How is the subject able to act politically?' Her question is 'What are the conditions enabling plurality and freedom to come into being when people act in concert?' Arendt focuses on the surroundings, the setting in which people can interact with each other and then experience freedom between them. But pedagogy aims at enabling subjects, and it is successful when deprived individuals are led by an abled person to develop abilities they did not have before. However, Arendt does not pursue this way of thinking since it is inconsistent with her idea of freedom. On the other hand, Perica senses a paradox in Rancière's pedagogical approach since he seems to believe that the aesthetic has the function to form human beings who are able to live in a free political community. But how can the distance between the abled who create the better and the ones who are not yet enabled be bridged ( $\mathrm{p}$. 290)?

Perica analyses the semantics of public and private by exploring Arendt's and Ranciere's different theoretical approaches. But in the end, her main focus is on participation (public) and withdrawal (private). The shifting between the two is the challenging point. Who is able to shift? How can everybody be enabled to shift? What is hindering some and allowing others to shift from the private to the public, from invisibility to visibility? This conception leads to a restrictive understanding of the private and the public as a way to emancipation. But it also leaves many questions unanswered. Perica highlights the importance of pedagogy in enabling everybody to judge politically and, therefore, to participate. A more developed explanation of this theoretical move would have been helpful. The respect she shows to 'her' theorists by careful reconstruction might thus have been extended to her own thought, too. A more detailed explanation of her argument would have illustrated more forcefully her own amazing and smart theoretical thinking.

Sophia Ermert

Humboldt-Universität zu Berlin, Unter den Linden 6, 10099 Berlin, Germany ermert@rewi.hu-berlin.de 